\title{
Comfort testing in office chair design
}

\section{Evaluación de la comodidad en el diseño de sillas de oficina}

\author{
María Fernanda Maradei - García ${ }^{1}$, Zuli Galindo - Estupiñan ${ }^{2}$, Javier Castellanos - Olarte ${ }^{3}$ \\ ${ }^{1}$ Universidad Industrial de Santander, Colombia. Email: mafermar@uis.edu.co \\ ${ }^{2}$ Universidad de Guadalajara, México. Email: zulig89@gmail.com \\ ${ }^{3}$ Universidad Pontificia Bolivariana, Colombia. Email: javier.castellanos@upb.edu.co
}

Received: Octubre 29, 2016 Accepted: December 10, 2016 Final Version: December 30, 2016

\begin{abstract}
When ergonomic criteria are separately applied to the design of chairs, the feeling of comfort is not guaranteed. In this case, the aesthetic and perceptive features of the chair provide the sensations of comfort, and several studies have determined that comfort and discomfort present some characteristics that make them different from each other. Moreover, early perceptions by the user remain invariable when there is no interaction between the person and the object. Therefore, it can be assumed that if a device is considered comfortable after an initial experience of use, it may well not be thought as such after extended use. Based on this, the present research study aimed at establishing the differences in the perceptions of comfort of two chairs before and after extended sitting posture. Six subjects participated in this study, all they were women from 20 to 45 years of age, who usually perform office work in extended sitting posture, with a body mass index (BMI) ranging between 20 and $30 \mathrm{Kg} / \mathrm{m} 2$. In the experiment, four office tasks were assigned (reading, transcribing a text, handwriting and searching on the internet) during sixty minutes. The experiment was divided into two sessions, to use the two chairs subject of the study. Each participant was assessed at the same hour but on two different days. By means of the semantic differential, evaluations of visual perception were carried out by the participants before and after using the chair. The results reveal differences in the perception evaluation of both chairs before and after their use. In the case of the chair a, the assessment of the adjectives never decreased. This study shows that the pleasure provided by a product is not static and it does evolve by product time of use and manipulation. Even though there were no statistical differences in the adjective pairs studied when only one chair was examined, it was demonstrated that its perception might improve or worsen on the basis of time. Similarly, this perceptual behavior is not indifferent to the object, finding significant differences before and after use when comparing the chairs. Finally, this analysis tool provides better evidence on product functionality by indicating whether there are failures in the proposed design.
\end{abstract}

KEYWORDS: Comfort, Semantic differential, Visual perception.

\section{RESUMEN}

Cuando los criterios ergonómicos se aplican por separado al diseño de las sillas, la sensación de comodidad no está garantizada. En este caso, las características estéticas y perceptivas de la silla proporcionan las sensaciones de confort, y varios estudios han determinado que el confort y el malestar presentan algunas características que los hacen diferentes unos de otros. Además, los juicios iniciales del usuario permanecen invariables cuando no hay interacción entre la persona y el objeto. Por lo tanto, se puede suponer que, si un dispositivo se considera cómodo después de una experiencia inicial de uso, puede no ser pensado como tal después del uso prolongado. A partir de esto, el presente estudio de investigación trata las diferencias en las percepciones de comodidad de dos sillas antes y después de la postura sentada extendida. Seis sujetos participaron en este estudio, todas mujeres de entre 20 a 45 años de edad, que suelen realizar trabajos de postura sentada extendida, con un índice de masa corporal (IMC) entre 20 y $30 \mathrm{Kg} / \mathrm{m} 2$. En el experimento, se asignaron cuatro tareas de oficina (lectura, transcripción de texto, escritura a mano y búsqueda en Internet) durante sesenta minutos el experimento se dividió en dos sesiones, a fin de utilizar las dos sillas objeto del estudio. Cada participante se evaluó a la misma hora pero en dos días diferentes. Mediante el diferencial semántico, las evaluaciones de la percepción visual fueron realizadas por los participantes antes y después de usar la silla. Los resultados Revelan diferencias en la evaluación de la percepción de ambas sillas antes y después de su uso. En el caso

Este artículo puede compartirse bajo la licencia CC BY-ND 4.0 y se referencia usando el siguiente formato: F. Maradei, Z. T Galindo, J. Castellanos, “Comfort Testing in Office Chair Design” UIS Ingenierías, vol. 16, no. 1, pp. 69-74. Enero-Junio 2017. 
de la silla a, la evaluación de los atributos nunca disminuyó. Este estudio muestra que el placer proporcionado por un producto no es estático Y evoluciona sobre la base del tiempo de uso y manipulación del producto. Aunque no hubo Diferencias estadísticas en los pares de atributos estudiados cuando se examina sólo una silla, se demostró que su percepción Puede mejorar o empeorar sobre la base del tiempo. De manera similar, esta conducta perceptiva no es indiferente al objeto, Encontrando diferencias significativas antes y después del uso al comparar las sillas. Por último, esta herramienta de análisis provee Mejor evidencia sobre la funcionalidad del producto, indicando si hay fallas en el diseño propuesto.

PALABRAS CLAVE: Comodidad, Diferencial semántico, Percepción visual.

\section{INTRODUCTION}

Sitting posture is currently one of the most used positions when developing professional activities, and it has been object of study for a long time [1-5]. However, suggestions with the aim of generating wellbeing are generally oriented to ergonomic features and too little towards those that involve the user's sensory part. It is known that comfort differs from discomfort and both aspects must be considered in seat design.

Thus, as found in the review of the literature, a variety of authors have defined ergonomic criteria for office chairs design. Within the revealed values, particularly width, height, seat depth, as well as backrest, it must be considered that the magnitudes are contained within the framework of the population from which each author is based on [1, 2, 6-9]. Thus, the review of the literature shows, among others, that the use of backrest favours lordosis by generating less discomfort. Evidence shows that people prefer 3-cm-thick back support, but this can reach 5-cm-thick [10] and the seat must be adjustable when reclined [11]. Others claim to consider a space between the seat and the bottom edge of the backrest so that the hip can slide back producing the rotation of the pelvis [10]. Regarding the backrest's angle of inclination -measured between the torso and thighs- there are authors who demonstrate how angles greater than $130^{\circ}$ reduce the paraspinal muscle contraction causing less fatigue [2, 12]. It is important to bear in mind, however, that visual demands proper to office work can cause excessive flexion of the head which may result in future cervical pathologies.

The ergonomic criteria previously presented do not guarantee that the aesthetic and perceptive features of the chair provide sensations of comfort. Several studies have determined that comfort and discomfort are aspects that differ from each other [13-15]. Accordingly, the former goes hand-in-hand with biomechanical factors directly related to fatigue, while the latter with the perception of wellbeing provided by aesthetic elements.

An object with better formal-expressive features offers initial reactions defining whether or not it fulfills the user's needs, creating an immediate emotional impact
[16]. Thus "Attractive things really work better: attractive things make people feel good, which in turn make them think more creatively and, as a result, make them tolerant of minor difficulties" [16]. However, the visceral-appearance level is not a sole aspect in the evaluation scale; there is also the behavioural-use level which is related to the function, comprehensibility and usability of the object. People focus on the object's functionality and, thereby, on its usability leading to the interaction that results in pleasure [17]. For this reason, the design process should aim at seeking the user's needs always from a perspective that integrates its functional, emotional and aesthetic aspects.

It is known that objects are attractive to people by their bright colours, unusual and harmonious shapes, and unique materials, which will always be measured by each person's subjectivity. This can be thought as a first approach to the aesthetics of the object, which set the difference between what can be observed and what the object evokes. On the other hand, this initial judgement lasts only if there is no interaction with the object [15], this suggests that the appraisal studies involving comfort features must be carried out before and after the use of the object. Considering an object as comfortable after an initial experience of use can be misleading if tests are not being carried out after extended use of the object. Therefore, the relevance of the aesthetics of the object along with the sensation that its use brings, provide better results of its impact.

Based on this, this study aimed at establishing the differences in the perceptions of comfort of two chairs before and after extended sitting posture. For this purpose, researchers used an ordinary office chair and a chair modified by the I.D. Zuli Galindo in the research group of ergonomics, product and meaning (Grupo de Investigaciones Ergonomía, Producto y Significado GEPS) of the school of industrial design at the Universidad Industrial de Santander, as to carry out comparisons in a more general level.

\section{MATERIALS AND METHOD}

Six subjects participated in this study. The purpose was, if possible, to attribute the differences detected to the 
factor (time). Therefore the participants were from a homogenous population. The subjects were women from 20 to 45 years of age who usually perform office work in extended sitting posture with a body mass index (BMI) between 20 to $30 \mathrm{Kg} / \mathrm{m} 2$.

An arrangement of a factor was used where it was concluded that time influences on comfort response. The dependent variable was studied based on the modified semantic differential (Figure 1). A continuous straight $10-\mathrm{cm}$-long line was used to quantify the aesthetic value. This corresponds to the distance, in millimeters, between the scale's origin labelled with the negative adjective and the point established by the participant (the end labelled with the positive sign is the highest value given to an object and corresponds to the positive adjective to be evaluated, which is opposite to the one placed in the negative sign). For this case, the scale has 101 value levels and, considering that the data corresponds to a normal distribution, then it is possible to make statisticparametric analyses.

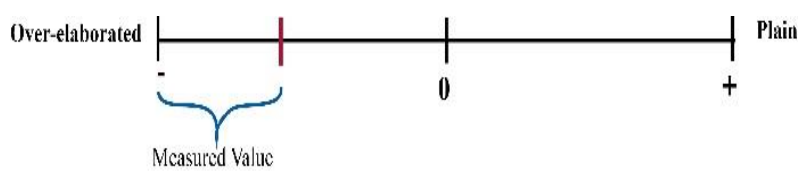

Figure 1. A continuous straight $10-\mathrm{cm}$-long line was used to quantify the aesthetic value based on the modified semantic differential. Source. Prepared by the authors

After presenting the project individually to the participants, and after being informed of the procedures, risks and privacy of the data collected, the participants signed the consent form. Then, the researchers collected the anthropometric data: age, weight and height.

Before the start of the test, an initial visual perception evaluation was carried out through the use of a modified semantic differential. Afterwards, the test started. Participants were told they had to perform four tasks in a period of 15 minutes each and in a specific order. Within one hour after the start of the test, a second visual perception evaluation of the chair was made. The chair's height was adjusted according to the anthropometric requirements of each participant, feet touched the ground and the angle formed by their legs had to be $90^{\circ}$; the backrest's inclination was $90^{\circ}$, measured from the seat (Figure 2).

Finally, the four tasks performed during the experimentation were: 1) reading, 2) transcribing a text, 3) handwriting and 4) surfing on the internet. Each task had a code as to be randomly assigned (see table 1).

An ANOVA test was used to compare the mean values of reported perception for each pair of adjectives before the chair A was used and after, the same was done for chair B. The mean values of reported perception before the use of chair A and chair B were compared with an ANOVA test, the same statistical analysis was made to compare after use mean values of reported perception between the two chairs.
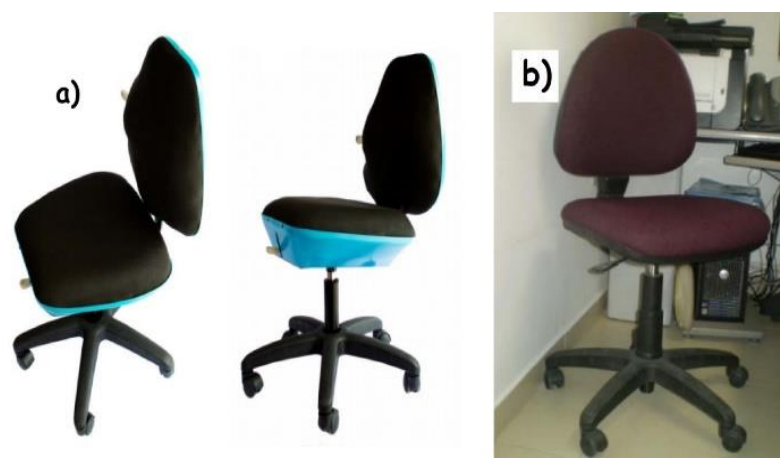

Figure 2. The two chairs used during the experimentation. Chair "a" was designed by the group GEPS. Source. Repared by the authors

Table1. Randomization of tasks.

\begin{tabular}{|c|c|c|c|c|c|c|c|c|} 
Participants & \multicolumn{9}{c|}{ Tasks with chair } \\
& "a" Tasks with chair \\
& 1 & 2 & 3 & 4 & 1 & 2 & 3 & 4 \\
\hline 1 & 2 & 3 & 1 & 4 & 1 & 2 & 3 & 4 \\
\hline 2 & 4 & 2 & 3 & 1 & 4 & 1 & 2 & 3 \\
\hline 3 & 1 & 3 & 4 & 2 & 3 & 4 & 1 & 2 \\
\hline 4 & 2 & 1 & 3 & 4 & 2 & 3 & 4 & 1 \\
\hline 5 & 4 & 2 & 1 & 3 & 1 & 2 & 4 & 3 \\
\hline 6 & 3 & 4 & 2 & 1 & 3 & 1 & 2 & 4 \\
\hline
\end{tabular}

Source. Repared by the authors.

\section{RESULTS}

The population presented an average age of 31,3 years of age with 9.85 of standard deviation (SD); $1.6 \mathrm{~m}$ of height (5.25 ft) (SD 0.059); a weight of $52.5 \mathrm{~kg}(115.74 \mathrm{lbs})$ and a BMI within the normal margin (20 to $30 \mathrm{Kg} / \mathrm{m} 2)$.:

The data in Table 2 show that even though, after comparing the means, it is concluded that there is no significant differences between the pairs of adjectives (except for the pair adjective: rigid/flexible), an improvement in all the adjectives examined, including comfort, in the chair A was found. In some cases, there were no changes in the perception of qualifying adjectives between chair A and B. However, chair a's perceptive valuation did not decrease in any of the cases. In others, there was a difference of more than 3 points with identical values of standard deviation. 
Table 2. Descriptive results before and after using chair a and comparison of measurements through anova.

\begin{tabular}{|c|c|c|c|}
\hline Adjective pairs & $\begin{array}{c}\text { Before } \\
\text { usage }\end{array}$ & $\begin{array}{c}\text { After } \\
\text { usage }\end{array}$ & p-valor \\
\hline $\begin{array}{c}\text { Over- } \\
\text { elaborated/plain }\end{array}$ & $\begin{array}{c}7.7 \\
(1.56)\end{array}$ & $\begin{array}{c}9.45 \\
(1.34)\end{array}$ & 0.149 \\
\hline Horrible/ Pretty & $\begin{array}{c}8.85 \\
(0.4)\end{array}$ & $\begin{array}{c}9.4 \\
(0.87)\end{array}$ & 0.531 \\
\hline Confusing/Clear & $\begin{array}{c}5.2 \\
(2.5)\end{array}$ & $\begin{array}{c}8.9 \\
(2.4)\end{array}$ & 0.259 \\
\hline Rigid/flexible & $\begin{array}{c}7.35 \\
(1.73)\end{array}$ & $\begin{array}{c}9.4 \\
(0.92)\end{array}$ & 0.032 \\
\hline Dirty/Clean & 9.15 & 9.45 & 0.369 \\
& $(0.6)$ & $(0.43)$ & \\
\hline Cold/Warm & $5(2.95)$ & $5(3)$ & 0.612 \\
\hline Firm/Mobile & $\begin{array}{c}9.1 \\
(1.8)\end{array}$ & $\begin{array}{c}9.6 \\
(0.52)\end{array}$ & 0.195 \\
\hline Uncomfortable/C & $\begin{array}{c}8.75 \\
\text { omfortable }\end{array}$ & $\begin{array}{c}9.35 \\
(1.8)\end{array}$ & 0.212 \\
\hline
\end{tabular}

Source. Repared by the authors.

In the case of chair B (table 3), the data show that the visual perception worsened in most of the adjective pairs including the criterion uncomfortable/comfortable, where, only in this case, they were statistically different (sig 0.05).

Table 3. Descriptive results before and after using chair $\mathrm{b}$ and comparison of measurements through ANOVA.

\begin{tabular}{|c|c|c|c|}
\hline Adjective pairs & $\begin{array}{c}\text { Before } \\
\text { usage }\end{array}$ & $\begin{array}{c}\text { After } \\
\text { usage }\end{array}$ & p-valor \\
\hline $\begin{array}{c}\text { Over- } \\
\text { elaborated/plain }\end{array}$ & $\begin{array}{c}7.6 \\
(1.5)\end{array}$ & $6.8(1.53)$ & 0.367 \\
\hline Horrible/ Pretty & $\begin{array}{c}6.4 \\
(2.2)\end{array}$ & $6.1(3.36)$ & 0.531 \\
\hline Confusing/Clear & $\begin{array}{c}7.8 \\
(1.73)\end{array}$ & $7(1.5)$ & 0.807 \\
\hline Rigid/flexible & $\begin{array}{c}6.05 \\
(2.4)\end{array}$ & $3.35(3.9)$ & 0.181 \\
\hline Dirty/Clean & $\begin{array}{c}6.1 \\
(3.7)\end{array}$ & $4.95(2.3)$ & 0.777 \\
\hline Cold/Warm & $5(1.36)$ & $5.5(1.28)$ & 0.188 \\
\hline Firm/Mobile & $\begin{array}{c}8.4 \\
(2.4)\end{array}$ & $6.55(2.9)$ & 0.347 \\
\hline $\begin{array}{c}\text { Uncomfortable/C } \\
\text { omfortable }\end{array}$ & $\begin{array}{c}7.15 \\
(1.46)\end{array}$ & $4.3(2.7)$ & 0.056 \\
\hline & & & \\
\hline
\end{tabular}

Source. Repared by the authors

Comparisons between the chairs were also made aiming at establishing their visual perception before and after usage. As table 4 shows, it was observed that both chairs are similarly evaluated before their use as there are no statistical differences between them, except for the adjective pairs Horrible/Pretty and Dirty/Clean. It can also be noted that the perception begins to change after an hour of use. Significant differences were found in almost every adjective pair studied. This agrees with the data previously obtained as while the visual perception of the chair improves the same aspect worsens for chair B.

Table 4. Comparison of chairs a and $b$ before and after usage.

\begin{tabular}{|c|c|c|}
\hline \multirow{2}{*}{$\begin{array}{c}\text { Visual Perception of } \\
\text { chairs a and b }\end{array}$} \\
\cline { 2 - 3 } Adjective pairs & $\begin{array}{c}\text { Before } \\
\text { usage }\end{array}$ & After usage \\
\hline $\begin{array}{c}\text { Over- } \\
\text { elaborated/plain }\end{array}$ & 0.97 & 0.03 \\
\hline Horrible/ Pretty & 0.02 & 0.021 \\
\hline Confusing/Clear & 0.373 & 0.521 \\
\hline Rigid/flexible & 0.382 & 0.00 \\
\hline Dirty/Clean & 0.045 & 0.00 \\
\hline Cold/Warm & 0.568 & 0.427 \\
\hline Firm/Mobile & 0.616 & 0.023 \\
\hline Uncomfortable/ & 0.442 & 0.00 \\
Comfortable & & \\
\hline
\end{tabular}

Source. Repared by the authors.

\section{CONCLUSIONS}

As Jordan (2000) suggests, users' needs are classified in three sequential levels which, added to them, is the interaction with the object itself [17]. These needs start from functionality, going through usability and end at the feeling of pleasure provided by the interaction with or use of a product. This model permits to explain the results as this study is not only limited to register data about the visual perception of a product which has not been used, but it enables to show how this perception changes on the basis of time.

Thus, the initial objective searched for establishing the differences in the perceptions of comfort of the chairs before and after extended use in sitting posture. The data indicate that the pleasure provided by a product is not static and it does evolve on the basis of product time of use and manipulation. Even though there were no statistical differences in the adjective pairs studied, when only one chair is examined, it was demonstrated that its perception might improve or worsen on the basis of time.

Likewise, this perceptual behaviour is not indifferent to the object, finding significant differences before and after use when comparing the chairs. That is, the data obtained agree with other studies like Jordan's (2000)[17] and 
Norman's (2005)[16] as it is necessary to have interaction in order to reach the reflexive level which, in turn will enable to get physical, social and psychological pleasure from a product.

On the other hand, thanks to the use of the semantic differential, it was possible to determine an object's connotative value through the interpretation of the emotions generated by the chair in quantitative values [18]. Nevertheless, the original method proposed by Osgood does not allow the realization of robust statistical analyses, for this reason, the data collection tool was modified based on the analog visual scales. This modification strengthened this study as it enabled to obtain continuous data from quantitative data. It also permitted the comparison of measurements through ANOVA.

Finally, the literature shows evidence of the combination of objective measurements as: the exerting pressure by the body over the seat or electromagnetic activity of the muscles, and the subjective valuation scales as the one carried out in this project, enhance the design quality of the chair in terms of comfort and discomfort [13]. However, it is important to clarify that these objective measurements are generally used to test discomfort, but not comfort criteria [19-21]. Still, it has been discovered that the distribution of the pressure over the seat seems to be the objective measurement that is best associated with the subjective scales [13].

\section{RECOMMENDATIONS}

It is suggested that the product to be analyzed before and after use in further research, as to reach an excellent response from the proposed design. This analysis tool may provide better proof of a design's functionality as the reaction of comfort must remain similar before and after its use; if values near or below zero are found, it can indicate flaws in the design which would lead to failing to fulfill the object's functions.

\section{REFERENCES}

[1] D. B. Chaffin, G. B. Andersson, and B. J. Martin, Occupational Biomechanics. New York: J. Wiley \& Sons., 2006.

[2] M. R. Jouvencel, Ergonomía Básica. Aplicada a la medicina del trabajo. Madrid, España.: Ediciones Diaz Santos, 1994.

[3] S. M. McGill, N. S. Kavcic, and E. Harvey, "Sitting on a chair or an exercise ball: Various perspectives to guide decision making," Clinical biomechanics (Bristol, Avon), vol. 21, no. 4, pp. 353-360, 2006.
[4] M. G. M. Thariq, H. P. Munasinghe, and J. D. Abeysekara, "Designing chairs with mounted desktop for university students: Ergonomics and comfort," International Journal of Industrial Ergonomics, vol. 40, no. 1, pp. 8-18, Jan 2010.

[5] Vargas, S. M. C., \& Porras, H., "Estimación De Los Factores De Penalización Del Tiempo En La Función De Costo Generalizado en Bucaramanga y su Área Metropolitana", Revista UIS Ingenierías, vol 15, no.2, pp.135-144, 2016.

[6] D. D. Harrison, S. O. Harrison, A. C. Croft, D. E. Harrison, and S. J. Troyanovich, "Sitting biomechanics Part I: Review of the Literature," Journal of manipulative and physiological therapeutics, vol. 22, no. 9, pp. 594609, 1999.

[7] M. Maradei Garcia, F. Espinel Correal, and A. Peña, "Estudio de valores antropométricos para la región nororiental colombiana" UIS Ingenierías, Vol.7, no 2, pp. 153-167, 2009.

[8] A. R. Tilley, The measure of man and women. New York: John Wiley \& sons, Inc., 2002, p. 98.

[9] M. Maradei Garcia, F. Espinel Correal, and L. Diaz, "Diseño de una Plataforma Informática para el Almacenamiento y Análisis de Datos Antropométricos. Antropos 2.0," UIS Ingenierías, Vol.7, no 1, pp. 41-52, 2008.

[10] S. M. Carcone and P. J. Keir, "Effects of backrest design on biomechanics and comfort during seated work," Applied Ergonomics, vol. 38, no. 6, pp. 755-764, Nov 2007.

[11] C. García, R. Moraga, A. Page, L. Torosa, and V. Verde, Guia de recomendaciones para el diseño de mobiliario ergonómico. España: Instituto de Biomecánica de Valencia, 1992.

[12] B. J. Andersson, R. Ortengren, A. L. Nachemson, G. Elfström, and H. Broman, "The sitting posture: an electromyographic and discometric study," The Orthopedic clinics of North America, vol. 6, no. 1, pp. 105-120, 01/ 1975.

[13] M. P. de Looze, F. M. Kuijt-evers, and J. Van Dieen, "Sitting comfort and discomfort and the relationships with objective measure," Ergonomics, vol. 46, pp. 985997, 2003.

[14] M. G. Helander and L. Zhang, "Field studies of comfort and discomfort in sitting," Ergonomics, vol. 40, no. 9, pp. 895-915, 1997. 
[15] L. Zhang, M. G. Helander, and C. G. Drury, "Identifying factors of comfort and discomfort in sitting," Human Factors: The Journal of the Human Factors and Ergonomics Society, vol. 38, no. 3, pp. 377-389, 1996.

[16] D. A. Norman, El diseño emocional: por qué nos gustan (o no) los objetos cotidianos. 2005.

[17] P. Jordan, Designing pleasurable products: An introduction to the new human factors. CRC Press, 2000.

[18] C. E. Osgood, The measurement of meaning. University of Illinois Press, 1957.

[19] S. Na, S. Lim, H. S. Choi, and M. K. Chung, "Evaluation of driver's discomfort and postural change using dynamic body pressure distribution," International Journal of Industrial Ergonomics, vol. 35, no. 12, pp. 1085-1096, Dec 2005.

[20] M. Vergara and A. Page, "Relationship between comfort and back posture and mobility in sittingposture," Applied Ergonomics, vol. 33, no. 1, pp. 1-8, Jan 2002.

[21] P. Vink, M. Franz, I. Kamp, and R. Zenk, "Three experiments to support the design of lightweight comfortable vehicle seats," Work: A Journal of Prevention, Assessment and Rehabilitation, vol. 41, no. 0, pp. 1466-1470, 01/01/ 2012. 